\title{
Anti-gastritic Effects of Magnolol and Honokiol from the Stem Bark of Magnolia obovata
}

\author{
So Yean $\mathrm{CHO}^{1}$, Je-Hyuk LeE ${ }^{2}$, Ki Hwan BAE${ }^{3}$, Yeong Shik Kıм", and Choon Sik JeONG ${ }^{1 *}$ \\ ${ }^{1}$ College of Pharmacy, Duksung Women's University, Seoul 132-714, Korea \\ ${ }^{2}$ Plant Resources Research Institute, Duksung Women's University, Seoul 132-714, Korea \\ ${ }^{3}$ College of Pharmacy, Chungnam National University, Daejeon 305-764, Korea \\ ${ }^{4}$ Natural Products Research Institute, Seoul National University, Seoul 110-460, Korea
}

(Received July 21, 2008; Revised July 25, 2008; Accepted August 27, 2008)

\begin{abstract}
In this study we investigated the effects of Magnolia Bark (MB) extract and its constituents, such as honokiol and magnolol, on gastritis in rats and the growth of human gastric cancer cells. The MB extract, honokiol, and magnolol showed the acid-neutralizing capacities, the antioxidant activities, and the inhibitory effect on the growth of Helicobacter pylori (H. pylori.) at the dose of $50 \mu \mathrm{g} / \mathrm{ml}$ and over, which is equivalent to that of ampicillin $(100 \mu \mathrm{g} / \mathrm{ml})$. Honokiol and magnolol had no significant cytotoxicity to human gastric caner cells (AGS and SNU638). However, the MB extract had cytotoxic activity against AGS gastric cancer cell. The MB extract, honokiol, and magnolol significantly inhibited $\mathrm{HCl}$-ethanol-induced gastric lesions without clear change of mucus content. In pylorus ligated rats, honokiol significantly decreased the volume of gastric secretion and gastric acid output, and increased the $\mathrm{pH}$. Magnolol increased the mucus content to almost the same as the control group at oral doses of $50 \mathrm{mg} / \mathrm{kg}$. Therefore, we could guess that antigastritic action of honokiol and magnolol may be associated with the antioxidant activities, acid-neutralizing capacities, inhibition of secretion in gastric acid, and anti-H. pylori action. From these results, we could suggest that MB extract and its constituents, such as honokiol and magnolol, may be useful for the treatment and/or protection of gastritis.
\end{abstract}

Keywords: Magnolia Bark (MB), Honokiol, Magnolol, Gastritis, Helicobacter pylori

\section{INTRODUCTION}

For some people who suffer from recurring gastritis and gastric ulcers, the pathological condition of these diseases causes an imbalance between aggressive factors (i.e., gastric acid, pepsin, stimulation of the vagus nerves, secretion of gastrin, and increasing the number of parietal cells) and protective factors (i.e., bicarbonate ion, mucus productivity, mucus secretion, and prostaglandins) (Shay et al., 1945). Physiological factors include acid-pepsin secretion, parietal cell activity, mucosal barrier, mucus secretion, blood flow, cell regeneration, and the release of endogeneous protective agents, especially prostaglandins and epidermal growth factors (Gyires, 2005). One of the greatest concerns is to ascertain whether the final outcome of Helicobacter pylori $(H$.

\footnotetext{
${ }^{*}$ Corresponding author

Tel: +82-2-901-8382, Fax: +82-2-901-8386

E-mail: choonsik@duksung.ac.kr
}

pylori)-induced gastritis may lead to gastric cancer. According to several epidemiologic studies concerning the association between gastric cancer and $H$. pylori, the positive rate of $H$. pylori antibody was shown to be higher in the patients with gastric cancer than in the control group (Kusters et al., 2006). In addition, the numerous approaches for the treatment of gastric ulcers have been focused on the control of acid secretion, $H$. pylori level and $\mathrm{H}^{+} / \mathrm{K}^{+}$-ATPase activity, in attempt to reverse mucosal damage and inflammation (Woo et al., 1998).

Magnolia Bark (MB) has been used as herbal medicine for gastrointestinal disorders, cough, anxiety, and allergic diseases in China, Korea, Japan, and other Asia countries. Recently, the pharmacological activities of MB extract and its components have defined, such as anti-inflammatory activity, an antidepressant effect, an inhibition of tumor metastasis, protection against cerebral ischaemic injury, an anti-platelet effect, and an antioxidant effect (Nakazawa et al., 2003; Ikeda et al., 2003; Chang et al., 2003; Pyo et al., 2002; Lo et al., 1994). In addition, it was has been reported 
that MB extract components had the pharmacological activities, such as the prevention of skin photoageing via inhibition of nuclear factor KB of magnolol (Tanaka et al., 2007), effect on transforming growth factor (TGF)- $\beta 1$, and fibronectin expression in human retinal pigment epithelial cells under diabetic conditions of magnolol (Kim et al., 2007).

The present work was carried out to investigate the anti-ulcerogenic effects of MB extract and its several constituents on gastritis in rats. The results of this study suggest that MB may be a good candidate for the development of new drugs or neutraceuticals which can be used for the treatment or prevention of gastritis.

\section{MATERIALS AND METHODS}

\section{Materials}

The dried bark of Magnolia obovata was purchased from Tokyo, Japan in March 2005. The plant was identified by Prof. Ki Hwan Bae, Chungnam National University, Daejeon, Korea. The voucher specimen (CNU-594) was deposited at the herbarium of the College of Pharmacy, Chungnam National University, Daejeon, Korea.

Human gastric cancer cell lines (AGS and SNU-638) were from Korean Cell Line Bank (Seoul, Korea), and $H$. pylori were obtained from American Type Culture Collection (ATCC) (Rockville, MD). Fetal bovine serum (FBS), RPMI medium 1640, and Hank's balanced salt solution were obtained from GIBCO Co. (Grand Island, NY). 1,1Diphenyl-2-picrylhydrazyl (DPPH), dantrolene sodium, 3(4,5-dimethylthiazol-2-yl)-2,5-diphenyl tetrazolium bromide (MTT), trypan blue, probenecid, dimethyl sulfoxide, sodium bicarbonate, penicillin-streptomycin, trypsin-EDTA, cimetidine, and ampicillin were obtained from Sigma Chemical Co. (St. Louis, MO). Silica gel 60, Kieselgel 60, Kieselgel 77, and TLC plate were from MERCK, Ltd. (Darmstadt, Germany). All other reagents and solvents for extraction were pharmaceutical or analytical grade.

\section{Animals}

Male Sprague-Dawley rats, weighing 180-200 g, were purchased from Samtako Inc. (Osan, Korea). Solid food and water were supplied ad libitum. All animals were housed and controlled on a $12 \mathrm{~h}$ light/dark cycle at $60 \pm 1 \%$ humidity and a temperature of $23.5 \pm 1.5^{\circ} \mathrm{C}$. The samples dissolved in saline were administered in a volume of $0.5 \mathrm{ml}$ per $100 \mathrm{~g}$ (body weight). The control group was given saline only. The experimental procedures for SpragueDawley rats were conducted in accordance with the Guidelines of the Care and Use of Laboratory Animals, Duksung
Women's University. The animals were allowed free access to food (standard pellet diet) and water ad libitum. All this study was carried out in compliance with the Testing Guidelines for Safety Evaluation of Drugs (Notification No. 199961) issued by the Korea Food and Drug Administration, the Good Laboratory Practice Regulations for Non-clinical Laboratory Studies (Notification No. 2000-63) issued by the Korea Food and Drug Administration, and the Principles of Good Laboratory Practice issued by the Organization for Economic Cooperation and Development.

\section{Extraction and isolation}

The stem bark of Magnolia obovata $(20 \mathrm{~kg}$ ) was extracted with methanol $(\mathrm{MeOH})$ three times under reflux for $4 \mathrm{~h}$. The $\mathrm{MeOH}$ solutions were combined, filtered and concentrated to yield a dry $\mathrm{MeOH}$ extract $(4 \mathrm{~kg})$. The $\mathrm{MeOH}$ extract $(4 \mathrm{~kg})$ was suspended in distilled water and fractionated with hexane, ethyl acetate (EtOAc), and butanol $(\mathrm{BuOH})$ to give a hexane soluble fraction $(600 \mathrm{~g})$, an EtOAc soluble fraction $(1,000 \mathrm{~g})$, and a $\mathrm{BuOH}$ soluble fraction $(800 \mathrm{~g})$, respectively. The hexane soluble fraction was separated over a silica gel column using hexane-EtOAc (100:0 50:50) to afford nine fractions (H1$\mathrm{H} 9)$. Fraction $\mathrm{H} 7$ was further separated on a silica gel column using hexane-EtOAc (20:1) to obtain crude crystal which was purified with crystallization in $\mathrm{CHCl}_{3}$ to give compound $\mathbf{1}(15 \mathrm{~g})$. Also, the fraction H9 was further separated on a silica gel column eluting with hexane-EtOAc (10:1) to obtain crude crystals which was purified with crystallization in $\mathrm{CHCl}_{3}$ to give compound $2(10 \mathrm{~g})$. The EtOAc soluble fraction was separated over a silica gel column eluting with $\mathrm{CHCl}_{3}-\mathrm{MeOH}(100: 1 \sim 2: 1)$ to afford twelve fractions (E1-E12). Fraction E5 was further sepa-
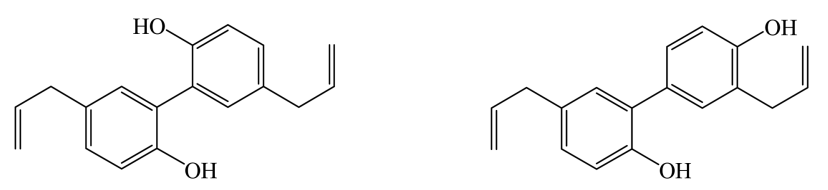

magnolol (1) honokiol (2)

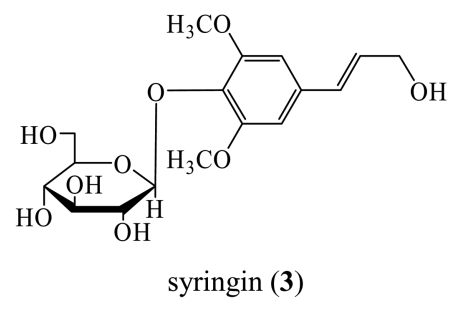

Fig. 1. Chemical structure of magnolol, honokiol, and syringi. 
rated on a silica gel column using $\mathrm{CHCl}_{3}-\mathrm{MeOH}$ $(50: 1 \sim 10: 1)$ to afford four fractions (E5.1-E5.4). Fraction E5.3 was subjected to a silica gel column using $\mathrm{CHCl}_{3}{ }^{-}$ $\mathrm{MeOH}$ (50:1 10:1) to give compound 3 (500 mg).

sThe compounds were identified as magnolol (1) (Shoji et al., 1991), honokiol (2) (Shoji et al., 1991), and syringin (3) (Valerie et al., 2001), by comparison of the physico-chemical and spectroscopic data with those of published papers (Fig. 1).

\section{Acid-neutralizing capacity}

MB extract $(1 \mathrm{mg})$ was added to $100 \mathrm{ml}$ of $0.1 \mathrm{~N} \mathrm{HCl}$ and then incubated for $1 \mathrm{~h}$ at $37^{\circ} \mathrm{C}$ shaking incubator. Acid-neutralizing capacity was determined by titrating with $0.1 \mathrm{~N} \mathrm{NaOH}$ using methyl orange as an indicator. Hydrotalcite was used as a positive control.

\section{Determination of antioxidant activity}

DPPH $(150 \mu \mathrm{M}, 1 \mathrm{ml})$ in methanol was added to $4 \mathrm{ml}$ of extracts and active constituents at the dose of 120,80 , $40,20,10,5$ and $2.5 \mu \mathrm{g} / \mathrm{ml}$ and then the mixture was stirred. After $30 \mathrm{~min}$ incubation period at room temperature, the absorbance of the test samples was read against a blank at $520 \mathrm{~nm}$. Inhibition free radical DPPH in percent $(\%)$ was calculated as followings : $\%=\left(A_{\text {blank }}-\right.$ $\left.A_{\text {sample }} / A_{\text {blank }}\right) X 100 . A_{\text {blank }}$ is the absorbance of the control reaction and $A_{\text {sample }}$ is the absorbance of the test samples. Concentration providing $50 \%$ inhibition $\left(\mathrm{IC}_{50}\right)$ was determined from the graph plotted inhibition percentage against concentration. L-Ascorbic acid was used as positive control.

\section{Anti-H. pylori activity}

H. pylori strain (HP ATCC 43504) was obtained from ATCC (Rockville, MD). The inhibitory effect of MB extract and its constituents on the growth of $H$. pylori was investigated. Samples $(600 \mu l)$ of each concentration were injected to $5.4 \mathrm{ml}$ of brucella agar medium contained $7 \%$ horse serum in the petri dish. H. pylori of $5 \times 10^{5} \mathrm{CFU}$ was seeded in this media and then incubated for 3 days at $37^{\circ} \mathrm{C}$ incubator (AnaeroPak Campylo : $85 \% \mathrm{~N}_{2}, 10 \% \mathrm{CO}_{2}$, $5 \% \mathrm{O}_{2}$ ). Ampicillin was used as a positive control.

\section{Cell culture and cell viability assay}

Gastric cancer cells were grown at $37^{\circ} \mathrm{C}$ in a humidified incubator under a $5 \% \mathrm{CO}_{2} / 95 \%$ air mixture in a MEM supplemented with 10\% FBS, 200,000 IU/I penicillin, 200 $\mathrm{mg} / \mathrm{l}$ of streptomycin, and $1 \mathrm{mM}$ sodium pyruvate. Culture medium was replaced every other day. After reachsing confluence, the cells were subcultured follow- ing trypsinization.

Cell viability was assessed by the MTT staining method (van de Loosdrecht et al., 1991). Cells from 4- to 5-day-old cultures were seeded in 24-well plates at the density of $5 \times 10^{4}$ cells/well. The volume of the medium in the wells was $1 \mathrm{ml}$. In control experiments cells were grown in the same media containing drug-free vehicle. After incubation with drug for 1 day, $100 \mu$ of MTT ( $5 \mu \mathrm{g} /$ l) were added and cells incubated for a further $4 \mathrm{~h}$. Two hundred microliters of DMSO were added to each culture and mixed by pipetting to dissolve the reduced MTT crystals. Relative cell viability was obtained by scanning with an ELISA reader (Molecular Devices, Menlo Park, CA) with a $540 \mathrm{~nm}$ filter.

\section{$\mathrm{HCl} \cdot$ ethanol-induced gastric lesion}

The rats, which were fasted for $24 \mathrm{~h}$ with free access to water prior to the experiment, were orally administered with the test substances (Mizui and Dodeuchi, 1983). After $30 \mathrm{~min}, 0.5 \mathrm{ml} / 100 \mathrm{~g}$ of a HClethanol $(150 \mathrm{mM} \mathrm{HCl}$ in $60 \%$ ethanol) solution was given orally for the induction of gastric lesions. One hour later, the animals were anesthetized with ether, and their stomachs were removed and fixed with $2 \%$ formalin for $10 \mathrm{~min}$. The amount of hemorrhage on the glandular portion was measured by summing the total length $(\mathrm{mm})$ of each lesion and expressed as a lesion index.

\section{Gastric secretion}

The male rats fasted for $24 \mathrm{~h}$ with free access to water, were immediately administered honokiol, magnolnol, or cimetidine intraduodenally (Shay et al., 1945). Four hours after the pyloric ligation, the animals were sacrificed and the contents of the stomach were collected and centrifuged at $1,650 \times \mathrm{xg}$ for $10 \mathrm{~min}$. The total gastric juice volume and $\mathrm{pH}$ were measured, and an acid output (mEq/ $\mathrm{ml}$ ) was determined by titrating of the gastric juice with $0.05 \mathrm{~N} \mathrm{NaOH}$ using phenolphthalein as an indicator.

\section{Mucus secretion}

Magnolol, honokiol, and sucrafate were administrated orally to the rats. After $30 \mathrm{~min}$, an ethanol $(1 \mathrm{ml} / 100 \mathrm{~g})$ was given orally to induce the gastric lesions. One hour later, the animals were sacrificed and the secreted mucus was determined (Kitagawa et al., 1986). The glandular portion separated from the excised stomach was opened along the lesser curvature and everted. The stomach was soaked in $0.1 \%$ alcian blue $8 \mathrm{GX}$ dissolved in $0.16 \mathrm{M}$ sucrose buffered with $0.05 \mathrm{M} \mathrm{CH}_{3} \mathrm{COONa}$ (adjusted to $\mathrm{pH}$ 5.8 with $\mathrm{HCl}$ ) for $2 \mathrm{~h}$. The mucus combined with the alcian 
blue was extracted with $20 \mathrm{ml}$ of $70 \%$ ethanol containing $30 \%$ dioctyl sodium sulfosuccinate and centrifuged for 10 min at 500xg. The optical density of the supernatant was measured at $620 \mathrm{~nm}$ using by UV-spectrophotometer (Agilent Technologies Inc., Santa Clara, CA, USA).

\section{Statistical analysis}

All experiments were performed four times if without specific designation. Data were expressed as mean \pm standard error of the mean (SEM) and were analyzed using one way analysis of variance (ANOVA) and Student-Newman-Keul's test for individual comparisons. $P$-values less than 0.05 are considered statistically significant.

\section{RESULTS AND DISCUSSION}

\section{Acid-neutralizing capacity}

As shown in Table I, the MB extract inhibited $5.04 \%$ of $\mathrm{NaOH}$ consumption volume, compared to the control. $\mathrm{NaOH}$ consumption volume of honokiol and magnolol was decreased to 11.65 and $12.62 \%$, respectively. In addition, syringin showed relatively low ANC (8.41\%). Antacids are effective in accelerating healing of duodenal and gastric ulcers. The ulcer healing action of antacids was thought to be due to the neutralization of gastric luminal acid (Tarnawski et al., 1995). In present study, the ANCs of MB extract and its components also might imply the increase of $\mathrm{pH}$ in gastric content in vitro. This suggests that ANC action may contribute for its gastroprotective effect. The acid neutralizing activity is triggered by a variety of conditions, ranging from stomach upset, heartburn, and nonulcer dyspepsia to verified gastric and duodenal ulcers. Although MB extract and its components had less acid

Table I. Acid-neutralizing capacity of the MB extract and its components

\begin{tabular}{ccc}
\hline Material & $\begin{array}{c}\mathrm{NaOH} \text { consumption } \\
(\% \text { control })\end{array}$ & Inhibition (\%) \\
\hline Control & $99.33 \pm 1.15$ & - \\
MB extract & $94.33 \pm 1.15$ & 5.04 \\
Magnolol & $87.38 \pm 1.88$ & 12.62 \\
Honokiol & $88.35 \pm 4.57$ & 11.65 \\
Syringin & $91.59 \pm 2.08$ & 8.41 \\
Hydrotalcite & $31.66 \pm 5.77$ & 68
\end{tabular}

MB extract $(1 \mathrm{mg})$ was added to $100 \mathrm{ml}$ of $0.1 \mathrm{~N} \mathrm{HCl}$ and then incubated for $1 \mathrm{~h}$ at $37^{\circ} \mathrm{C}$ shaking incubator. Acid-neutralizing capacity was determined by titrating with $0.1 \mathrm{~N} \mathrm{NaOH}$ using methyl orange as an indicator. Hydrotalcite was used as a positive control. The values are mean \pm SEM.
Table II. Free radical scavenging activity of MB extract and its components

\begin{tabular}{cc}
\hline Material & $\mathrm{IC}_{50}(\mu \mathrm{g} / \mathrm{ml})$ \\
\hline MB extract & 20.97 \\
Magnolol & 83.47 \\
Honokiol & 14.09 \\
Syringin & $>160$ \\
$\mathrm{~L}-$ Ascorbic acid & $<5$ \\
\hline
\end{tabular}

$\mathrm{DPPH}(150 \mu \mathrm{M}, 1 \mathrm{ml})$ was added to $4 \mathrm{ml}$ of $\mathrm{MB}$ extract and its components at the dose of $120,80,40,20,10,5$, and 2.5 $\mu \mathrm{g} / \mathrm{ml}$ and then the mixture was stirred. After 30 min incubation period at room temperature, the absorbance of the test samples was read against a blank at $520 \mathrm{~nm}$. Concentration providing $50 \%$ inhibition $\left(\mathrm{IC}_{50}\right)$ was determined from the graph plotted inhibition percentage against concentration

neutralizing capacity than hydrotalcite, it is expected it might be helped for the gastroprotective effect as nutraceuticals.

\section{Antioxidant activity}

The MB extract showed dose-dependent free radical scavenging activity as well as its components, such as honokiol and magnolol (Table II). The positive control Lascorbic acid showed $50 \%$ radical scavenging activity at $5 \mu \mathrm{g} / \mathrm{ml}$ and MB extract, honokiol, and magnolol inhibited DPPH radical at 20.97, 14.09 and $83.47 \mu \mathrm{g} / \mathrm{ml}$, respectively. Recently, the antioxidant activity of compounds has attracted interest because of strong evidence that oxidation processes are involved in the mechanisms of several gastric disorders, including ulcerogenesis (La Casa et al., 2000). Therefore, these results have suggested that MB ethanolic extract and its constituents with free radical scavenging activities might be used for treatment of gastric disorder.

\section{Anti-H. pylori activity}

$H$. pylori is the major worldwide cause of bacterial gastrointestinal infections. It is believed to be a major cause of peptic ulcer (Gerrits et al., 2006) and gastric cancer (Matysiak-Budnik and Megraud, 2006). Antibiotic therapy and a combination of two or three drugs have been widely used to eradicate these infections. However, the development of drug resistance in bacteria calls for new sources of drugs and plants seem to be a logical source of new antibacterial compounds. Indeed, the use of medicinal plants and/or their chemical components has been reported to have a potential benefit in eradicating such problems (Nostro et al., 2005). Recent researches for purified compounds from 
Table III. Anti-H. pylori activity of MB extract and its components

\begin{tabular}{ccc}
\hline Material & Dose $(\mu \mathrm{g} / \mathrm{ml})$ & Colonization \\
\hline Control & 10 & +++ \\
MB extract & 50 & ++ \\
& 100 & - \\
Magnolol & 10 & - \\
& 50 & ++ \\
Honokiol & 100 & - \\
& 10 & - \\
& 50 & ++ \\
Syringin & 100 & - \\
& 10 & +++ \\
Ampicillin & 50 & +++ \\
& 100 & ++ \\
\hline
\end{tabular}

+++: colonies $\left(4-5 \times 10^{5} \mathrm{CFU}\right) ;++$ : colonies $\left(2-4 \times 10^{5} \mathrm{CFU}\right)$; + : colonies $\left(0-2 \times 10^{5} \mathrm{CFU}\right)$; - : none

Samples $(600 \mu \mathrm{l})$ of each concentration were injected to 5.4 $\mathrm{ml}$ of brucella agar medium contained $7 \%$ horse serum in the petri dish. H. pylori (HP ATCC 43504) of $5 \times 10^{5}$ CFU was seeded in this media and then incubated for 3 days at $37^{\circ} \mathrm{C}$ incubator (AnaeroPak Campylo : $85 \% \mathrm{~N}_{2}, 10 \% \mathrm{CO}_{2}, 5 \% \mathrm{O}_{2}$ ).

peppers, wine and many other natural products have shown that phenolic phytochemicals such as cinnamic acids, cinnamaldehydes, coumarin, capsaicin, flavonoids, and tannins have high anti-H. pylori activity (Bae et al., 1999). From this study, we found that MB extract and its constituents had inhibitory effects on the growth of $H$. pylori as shown in Table III. The results showed that MB extract, magnolol, and honokiol have completely inhibited the colonization of $H$. pylori at the dose of 50 and $100 \mu \mathrm{g} / \mathrm{ml}$, and this effect was equipotent compared to that of ampicillin $(100 \mu \mathrm{g} / \mathrm{ml})$.

\section{Effect of MB extract and its components on the cell viability of SUN638 and AGS cell lines}

Cytotoxicity was assessed by measuring cell viability of human gastric cancer cells (AGS and SNU-638) using the MTT staining method. The MB extract had cytotoxicity against AGS gastric cancer cell. However, its components did not show cytotoxic activity (Table IV). Gastric cancer is a leading cause of cancer-related deaths, worldwide being second only to lung cancer as a cause of death (Neugut et al., 1996). For the prevention of gastric cancer disease, it is very important to develop the
Table IV. Effect of MB extract and its components on the cell viability of SUN638 and AGS cell lines

\begin{tabular}{ccc}
\hline Material & $\begin{array}{c}\text { SNU638 IC } \\
(\mu \mathrm{g} / \mathrm{ml})\end{array}$ & $\begin{array}{c}\mathrm{AGS} \mathrm{IC} \\
(\mu \mathrm{g} / \mathrm{ml})\end{array}$ \\
\hline MB extract & 387.55 & 51.25 \\
Magnolol & $>100$ & $>100$ \\
Honokiol & $>100$ & $>100$ \\
Syringin & $>100$ & $>100$ \\
\hline
\end{tabular}

Cell viability was assessed by the MTT method. Cells were seeded in 24-well plates at the density of $5 \times 10^{4}$ cells/well. After incubation with test materials for 1 day, $100 \mu \mathrm{l}$ of MTT $(5 \mu \mathrm{g} / \mathrm{l})$ were added and cells incubated for $4 \mathrm{~h}$. DMSO were added to each culture and mixed by pipetting. Relative cell viability was obtained by an ELISA reader with a $540 \mathrm{~nm}$.

natural herbal medicine to act to the cancer cells directly. Dietary components including flavonoids and carotenoids have potentially beneficial effects on gastric cancers. Recently, the development of new anticancer drug is a key issue for cancer chemotherapy because of the reality that cancer cells, which are resistant to chemotherapy, will eventually cause mortality. Herbal medicines as substitutes for cancer remedies have attracted a great deal of interest, because of their low toxicity and costs. Taken together, we could expect that MB extract might show the partly cytotoxic actions on human gastric cancer cells.

\section{Effect of MB extract-components on $\mathrm{HCl} \cdot$ ethanol- induced gastric lesion}

The $\mathrm{HCl} \cdot$ ethanol-induced gastric lesion appears to be produced by the direct irritation of a gastric mucosal barrier (Seiki et al., 1990). Ethanol induced both long ulcers and petechial lesions within a relatively short time, which makes this technique suitable for screening experiments for investigation of anti-ulcer drugs. The effects of $\mathrm{MB}$ ethanolic extract and its constituents on the $\mathrm{HCl} \cdot$ ethanolinduced lesion were investigated, and the results are shown in Table V. Lesion index induced by $\mathrm{HCl} \cdot$ ethanol addition of control group was $66.7 \pm 6.77 \mathrm{~mm}$, as depicted in Table V. Compared to this control, treatment with magnolol and honokiol significantly decreased lesion index, which was better than or equivalent to that of cimetidine (100 mg/kg), sucralfate (375 mg/kg) and hydrotalcite (100 $\mathrm{mg} / \mathrm{kg}$ ), which are positive controls. At the dose of $50 \mathrm{mg} /$ $\mathrm{kg}$, magnolol and honokiol significantly protected the gastric mucosal of rats by 66.25 and $12.25 \%$, respectively. And honokiol strongly protected by $80.78 \%$ against $\mathrm{HCl}$. ethanol induced ulcers in rats at the dose of $100 \mathrm{mg} / \mathrm{kg}$ and these activities showed the dose-dependently. 
Table V. Protective effect of $\mathrm{MB}$ extract-components on $\mathrm{HCl} \cdot$ ethanol-induced gastric lesion

\begin{tabular}{cccc}
\hline Material & $\begin{array}{c}\text { Dose } \\
(\mathrm{mg} / \mathrm{kg})\end{array}$ & $\begin{array}{c}\text { Lesion index } \\
(\mathrm{mm})\end{array}$ & Inhibition (\%) \\
\hline Control & - & $66.7 \pm 6.77$ & - \\
Magnolol & 50 & $22.5 \pm 4.58^{\star *}$ & 66.25 \\
& 100 & $56.9 \pm 8.84$ & 14.7 \\
Honokiol & 50 & $58.5 \pm 11.71$ & 12.25 \\
& 100 & $12.7 \pm 0.06^{\star \star}$ & 80.78 \\
Sucralfate & 375 & $26.5 \pm 0.10$ & 59.7 \\
Hydrotalcite & 100 & $36.8 \pm 0.28$ & 44.8 \\
Cimetidine & 100 & $45.7 \pm 0.30$ & 30.4 \\
\hline
\end{tabular}

The values are mean \pm SEM of 6 animals. ${ }^{* *} P<0.01$ compared to the control group

Table VI. Inhibitory effect of MB extract-components on the gastric secretion

\begin{tabular}{ccccc}
\hline Material & $\begin{array}{c}\text { Dose } \\
(\mathrm{mg} / \mathrm{kg})\end{array}$ & $\begin{array}{c}\text { Volume } \\
(\mathrm{ml})\end{array}$ & $\mathrm{pH}$ & $\begin{array}{c}\text { Total acid } \\
\text { output } \\
(\mathrm{mEq} / 4 \mathrm{~h})\end{array}$ \\
\hline Control & - & $5.4 \pm 2.53$ & $0.7 \pm 0.04$ & $0.47 \pm 0.02$ \\
Magnolol & 50 & $5.1 \pm 1.97$ & $1.3 \pm 0.03$ & $0.43 \pm 0.01$ \\
Honokiol & 100 & $4.06 \pm 0.90$ & $2.0 \pm 0.03$ & $0.29 \pm 0.04^{*}$ \\
Cimetidine & 100 & $2.8 \pm 1.35^{\star *}$ & $2.7 \pm 0.02$ & $0.09 \pm 0.01^{* \star}$ \\
\hline
\end{tabular}

Total gastric juice volume and $\mathrm{pH}$ were measured $4 \mathrm{~h}$ after the pyloric ligation. The values are mean \pm SEM of 6 animals. ${ }^{\star} P<0.05,{ }^{* *} P<0.01,{ }^{* *} P<0.001$ compared to the control group

\section{Effect of MB extract-components on the gastric secretion}

The effects of the MB extract and its constituents on gastric secretion and $\mathrm{pH}$ and acid output in pylorusligated rats were examined, and the results are shown in Table VI. We measured gastric-juice parameters, i.e., gastric volume and $\mathrm{pH}$, after submitting the rats to pylorus ligature with or without the MB constituents administered intraduodenally. Cimetidine was used for a positive control. Compared to control condition, the treatment with honokiol $(100 \mathrm{mg} / \mathrm{kg})$ significantly decreased the gastric secretion and acid output, and increased $\mathrm{pH}$, although that of induced by cimetidine $(100 \mathrm{mg} / \mathrm{kg})$ was superior. And magnolol had no significant change compared to the control in gastric secretion and acid output except for increase of $\mathrm{pH}$. Gastric ulcer seems to be generated from over-secretion of gastric juice and imbalance of defensive and aggressive factors involved in maintaining gastric mucosal integrity (McQuaid and Isenberg, 1992). The formation of gastric mucosal lesions by necro- tizing agents such as $\mathrm{HCl}$ and ethanol has been shown to be associated with depression of gastric defensive mechanisms (Kinoshita et al., 1995). Therefore, acid production regulators such as proton pump inhibitors widely used in clinic (Pisegna, 2002), appear to accelerate the healing of gastric ulcers and gastritis by potent and longlasting antisecretory actions (Welage, 2003). Thus these results suggest that the mechanism of honokiol, isolated from MB, by which it inhibited gastric ulcer and gastritis may be due to suppression of aggressive factors (i.e., inhibition of gastric acid secretion) and in turn, augmentation of defensive factors, like as proton pump inhibitors.

\section{Effect of MB extract-components on mucus secre- tion}

As shown in Table VII, magnolol increased the mucus content to almost the same as the control group at oral doses of $50 \mathrm{mg} / \mathrm{kg}$. In the mucus secretion model, even though ethanol was induced in the rats to reduce the amount of mucus secretion, magnolol enhanced the mucus secretion. Therefore, the gastroprotective activity of magnolol originated from the stimulation of mucus secretion. However, in order to demonstrate that magnolol stimulates the mucus secretion, the mucus secretion was examined to determine if it is stimulated in the absence of ethanol.

In this study, we investigated the effects of the MB extract and its components on gastritis in rats and growth of human gastric cancer cells. The extracts, honokiol, and magnolol have shown the acid-neutralizing capacities, antioxidant activities, and inhibition of growth of $H$. pylori. Honokiol and magnolol significantly inhibited $\mathrm{HCl}$.ethanolinduced gastric lesions. In pylorus ligated rats, honokiol significantly decreased the volume of gastric secretion and gastric acid output, and increased the $\mathrm{pH}$. Magnolol increased the mucus content to almost the same as the control. These results suggest that MB extract may be a good candidate for the development of new drugs or neutraceuticals which can be used for the treatment or pre-

Table VII. Protective effect of MB extract-componets on the ethanol induced gastric lesion in rats

\begin{tabular}{ccc}
\hline Material & Dose $(\mathrm{mg} / \mathrm{kg})$ & $\begin{array}{c}\text { Mucus content } \\
(\mu \mathrm{g} \text { as alcian blus })\end{array}$ \\
\hline Control & - & $122.8 \pm 7.91$ \\
Magnolol & 50 & $121.6 \pm 5.46$ \\
Honokiol & 100 & $105.6 \pm 7.21$ \\
Sucralfate & 100 & $155.6 \pm 8.23$ \\
\hline
\end{tabular}

The values are mean \pm SEM of 6 animals. 
vention of gastritis.

\section{ACKNOWLEDGEMENTS}

This study was supported by a grant from the Food \& Drug Administration, Republic of Korea and the Korea Research Foundation Grant funded by the Korean Government (MOEHRD, Basic Research Promotion Fund) (KRF-2005-005-J13002).

\section{REFERENCES}

Bae, E.A., Han M.J. and Kim, D.H. (1999) In vitro anti-Helicobacter pylori activity of some flavonoids and their metabolites. Planta Med. 65, 442-443.

Chang, C.P., Hsu, Y.C. and Lin, M.T. (2003) Magnolol protects against cerebral ischaemic injury of rat heatstroke. Clin. Exp. Pharmacol. Physiol. 376, 387-392.

Gerrits, M.M., van Vliet, A.H.M., Kuipers, E.J. and Kusters, J.G. (2006) Helicobacter pylori and antimicrobial resistance: molecular mechanisms and clinical implications. Lancet Infect. Dis. 6, 699-709.

Gyires, K. (2005) Gastric mucosal protection: from prostaglandins to gene-therapy. Curr. Med. Chem. 12, 203-215.

Ikeda, K., Sakai, Y. and Nagase, H. (2003) Inhibitory effect of magnolol on tumor metastasis in mice. Phytother. Res. 17, 933-937.

Kim, Y.S., Jung, D.H., Kim, N.H., Lee, Y.M. and Kim, J.S. (2007) Effect of magnolol on TGF- $\beta 1$ and fibronectin expression in human retinal pigment epithelial cells under diabetic conditions. Eur. J. Pharmacol. 562, 12-19.

Kinoshita, M., Noto, T. and Tamaki, H. (1995) Effect of a combination of ecabet sodium and cimetidine on experimentally induced gastric lesions and gastric mucosal resistance to ulcerogenic agents in rats. Biol. Pharm. Bull. 18, 223-226.

Kitagawa, H., Takeda, F. and Kohei, H. (1986) A simple method for estimation of gastric mucus and effects of antiulcerogenic agents on the decrease in mucus during water-immersion stress in rats. Arzneimittelforschung 36, 1240-1244.

Kusters, J.G. van Vliet, A.H. and Kuipers, E.J. (2006) Pathogenesis of Helicobacter pylori infection. Clin. Microbiol. Rev. 19, 449-490.

La Casa, C., Villegas, I., Alarcón de la Lastra, C., Motilva, V. and Martín Calero, M.J. (2000) Evidence for protective and antioxidant properties of rutin, a natural flavone, against ethanol induced gastric lesions. J. Ethnopharmacol. 71, 45-53.

Lo, Y.C., Teng, C.M., Chen, C.F., Chen, C.C. and Hong, C.Y. (1994) Magnolol and honokiol isolated from Magnolia officinalis protect rat heart mitochondria against lipid peroxidation. Biochem. Pharmacol. 47, 549-553.

Matysiak-Budnik, T. and Megraud, F. (2006) Helicobacter pylori infection and gastric cancer. Eur. J. Cancer 42, 708-716.
McQuaid, K.R. and Isenberg, J.I. (1992) Medical therapy of peptic ulcer disease. Surg. Clin. North Am. 72, 285-316.

Mizui, T. and Dodeuchi, M. (1983) Effect of polyamines on acidified ethanol-induced gastric lesion in rats. Jpn. J. Pharmacol. 33, 939-945.

Nakazawa, T., Yasuda, T. and Ohsawa, T. (2003) Metabolites of orally administrated Magnolia officinalis extract in rats and man and its antidepressant-like effects in mice. J. Pharmacol. 55, 1583-1591.

Neugut, A.I., Hayek, M. and Howe, G. (1996) Epidemiology of gastric cancer. Semin. Oncol. 3, 281-291.

Nostro, A., Cellini, L., Di Bartolomeo, S., Di Campli, E., Grande, R., Cannatelli, M. A., Marzio, L. and Alonzo, V. (2005) Antibacterial effect of plant extracts against Helicobacter pylori. Phytother. Res. 19, 198-202.

Pisegna, J. R. (2002) Pharmacology of acid suppression in the hospital setting: focus on proton pump inhibition. Crit. Care Med. 30, S356-S361.

Pyo, M.K., Lee, Y. and Yun-Choi, H.S. (2002) Anti-platelet effect of the constituents isolated from the bark and fruits of Magnolia ovata. Arch. Pharm. Res. 25, 325-328.

Seiki, M., Ukei, S., Tanaka, Y. and Soeda, M. (1990) Studies of anti-ulcer effects of a new compound, zinc L-carnosine (Z103). Nippon Yakurigaku Zasshi 95, 257-269.

Shay, H., Komarov, S.A., Fels, S.S. and Meranze, D. (1945) A simple method for the uniform production of gastric ulceration in the rat. Gastroenterol. 4, 43-61.

Shoji, Y., Takashi, N., Akihide, K., Toshihiro, N. and Itsuo, N. (1991) Isolation and characterization of phenolic compounds from Magnoliae Cortex produced in China. Chem. Pharm. Bull. 39, 2024-2036.

Tanaka, K., Hasegawa, J., Asamitsu, K. and Okamoto, T. (2007) Magnolia ovovata extract and its active component magnolol prevent skin photoaging via inhibition of nuclear factor кB. Eur. J. Pharmacol. 565, 212-219.

Tarnawski, A., Tanoue, K., Santos, A.M. and Sarfeh, I.J. (1995) Cellular and molecular mechanisms of gastric ulcer healings. Scand. J. Gastroenterol. Suppl. 210, 9-14.

Valerie, S., Hartmut, F., Ulrich, P. and Rodney, S. (2001) Coniferyl alcohol metabolism in conifers - I. Glucosidic turnover of cinnamyl aldehydes by UDPG: coniferyl alcohol glucosyltransferase from pine cambium. Phytochemistry 64, 1401-1404.

van de Loosdrecht, A.A., Nennie, E., Ossenkoppele, G.J., Beelen, R.H. and Langenhuijsen, M.M. (1991) Cell mediated cytotoxicity against U937 cells by human monocytes and macrophages in a modified colorimetric MTT assay. A methodological study. J. Immunol. Method. 141, 15-22.

Welage, L.S. (2003) Pharmacologic properties of proton pump inhibitors. Pharmacotherapy 23, 74S-80S.

Woo, T.W., Chang, M.S., Chung, Y.K., Kim, K.B., Sohn, S.K., Kim, S.G. and Choi, W.S. (1998) Inhibitory action of YJA20379, a new proton pump inhibitor on Helicobacter pylori growth and urease. Arch. Pharm. Res. 21, 6-11. 